\title{
ALGERIAN ISLAMISM. ANALYSIS OF ELITES AND RESOURCES IN MAJOR POLITICAL PARTIES AND SOCIAL MOVEMENTS (1990-2016) ${ }^{1}$
}

\author{
Rafael Bustos \\ Lecturer in International Relations at UCM \\ Researcher at UAM \\ rbustos@ucm.es
}

\section{SUMMARY}

This chapter represents an analysis, from the standpoint of the sociology of power, of the resources of Islamist elites in Algeria, specifically focusing on the three most important political parties: FIS, MSP (HAMAS) and en-Nahda between 1990 and 2016. This analysis, intentionally excluding armed groups, will try to explain the fundamental differences between the former party - a true mass movement - and the other two, which are circumscribed by their grassroots support and the circular logic of their relations with power. The different origins of their elites, their grassroots supporters and above all their political strategy all throw a light on the different paths followed by these three tendencies of the Islamist movement.

Key words: Algeria, political Islam, Islamism, elites, resources, strategies, democracy, political parties, social movements

\section{INTRODUCTION}

Under the new president Chadli Bendjedid, who ruled during the 1980s, the Islamist movement began to show a strength that is still emerging. One example was the mass demonstration of students in Algiers in 1982, which was brought to an end by the publication of a 14-point document of Islamist demands. This led to the house arrest of Sheikh Abdelatif Soltani, one of the document's signatories, and who died soon after while under arrest. The funerals held for Soltani in 1984 were attended by huge numbers of people, which represented another sign of Islamist strength. These two events were important moments in terms of the Islamist movement's visibility and affirmation in Algeria. Despite the clandestine work, the earlier years began to bear fruit in the milieu of the universities, where Islamist groups started to outnumber left-wing and pro-Berber groups.

\footnotetext{
${ }^{1}$ F. Izquierdo, J. Etherington and L. Feliu (eds.), Political Islam in a time of Revolt, [2017], Palgrave Macmillan, reproduced with permission of Palgrave Macmillan. This extract is taken from the author's original manuscript and has not been edited. The definitive, published, version of record is available here: https://www.palgrave.com/de/book/9783319528328.
} 
The mid-1980s saw an affirmation of Islamist strength in the form of the Bouyali terrorist group, the Armed Islamic Group. For several years, this small armed organisation perpetrated a number of acts of sabotage against state installations and infrastructures, though without causing personal injury. Bouyali, the group's mastermind, was captured and killed in 1987 and his group dissolved, after which Bouyali became a kind of romantic hero for Islamism. However, some of his group's members made a reappearance later in the early 1990s after the break-up of FIS and the outbreak of hostilities by Islamist factions and groups.

When the Islamists "reappeared" in 1988-89, firstly to take political advantage of the people's movement of October 1988 (later known as "les évènements") and subsequently to legalise certain parties, different tendencies and stances already existed within the movement. One tendency - as personified by the historical leaders - was opposed to following political channels, which they viewed with suspicion and distrust. There was also a gradualist tendency that had developed by working with civil society through charity and preaching associations, and which requested legalisation after FIS came onto the scene (HAMAS and En-Nahda al-Islamiyya). Furthermore, there was a populist trend disposed toward taking advantage of the opportunities made available by the regime, and which took to the streets in 1988 and led to the launching of the Islamic Salvation Front. Finally, there was a tendency that favoured violent action; these were the heirs of the Bouyali group, and had learned their lessons from the resources and the mistakes made by Bouyali, whom they considered naive and romantic. By way of clarification, I should add that the Association of Algerian Muslim Ulema, as such, was not involved with any of these tendencies (perhaps with the exception of the anti-political one). Admittedly, the Association tried to regain visibility during the "Algeria Spring", but it was inevitably eclipsed and overtaken by the dynamism of the new parties, especially by FIS.

Even the "al-yazara versus ad-dawliya or salafiya" debate (that is to say, between the "Algerianist" tendency and the "internationalists") had already become entrenched when the changes and events of the "Algeria Spring" commenced. Though this split was not very well known outside Islamist circles, it has to do with the interpretation of Islamism, and specifically the opposition that exists between those who favour a global Islamic state (ad-dawliya) headed by a caliphate, and those who support a national Islamic state (al-yazara) while respecting national borders and the particularities of the different nations. In the eyes of "international" Islamists, all states and their symbols are ungodly, in accordance with the activist thoughts of Sayid Qutb and Abu Ala Maududi. Therefore, these elements belong to "yahilyia", or the pre-Islamic age of ignorance, and as such must be destroyed and replaced by truly Islamic institutions. In Algeria, this split has tended to define itself as the struggle between those who support the line of Sheikh Ben Badis, famous ulema of the 1930s (and later the Algerian thinker Malek Bennabi) and those who support Wahhabi and other foreign radical Salafite thinkers.

After the conflict broke out in spring/summer of 1992, a number of armed Islamist groups appeared: MIA, MEI, AIS, FIDA, GIA, GSPC and, finally, al-Qaeda in the Islamic Maghreb (AQMI), to name just a few of the most important ones. Though the conflict had its origin in the cancellation of the electoral process in which FIS had gained a considerable majority in Parliament (January 1992) and the subsequent dissolving of 
FIS (March 1992), the violence only flared up in the months after these events. Despite the fact that 30,000 FIS militants (or 5,000, according to the Army) were arrested and held in detention camps in the Sahara, and in spite of the assassination of the president Mohamed Boudiaf, political violence did not take hold in the country until late 1992 and 1993, with the advent of the first armed resistance groups - the MIA (Islamic Armed Movement, of Abdelkader Chebouti), whose members had fought with Bouyali and had regrouped in 1990, and the MEI (Movement for an Islamic State, of Said Mekhloufi). The former was an almost secret elitist guerrilla group that only attacked members of the military forces, while the latter favoured outright terrorism (Martínez 2010).

The armed wing of FIS, the AIS (Islamic Salvation Army), did not take up arms until after these factions had appeared, in 1994. After these came others, which attacked the state, the resistance groups already in existence (they declared war on the FIS) and civil society, and which perpetrated widespread killings and murdered leading figures. These factions included FIDA-Islamic Front for Armed Jihad (specialized in killing intellectuals) and GIA-Armed Islamic Group (mass killings), and which later produced the splinter group GSPC (Salafist Group for Preaching and Combat). This group declared its loyalty to al-Qaeda in 2003, later becoming a branch of al-Qaeda under the name of AQMI in late 2006, though it disappeared as such in January 2007. After the truce (1997) and the break-up of AIS (2000), the conflict took a new direction which, from 2001 onwards, resulted in a significant reduction in violence. Even before the conflict had ended, many members of the resistance group surrendered, taking advantage of the successive laws on civil concord (1999) and national reconciliation (2005). The violence decreased and became restricted to a few mountainous areas in Kabylia, Boumerdés (centre) and Jijel (north-east), despite a number of kidnappings and spectacular attacks by AQMI in recent years, such as the ones (all in 2007) which targeted the government building and the Ministry of the Interior, the headquarters of ACNUR, UNDP and the Constitutional Court in the capital city, and an attack on the president of the republic himself while visiting the city of Batna.

However, this chapter does not propose to focus on the political history of the conflict or on the violent Islamist groups, as in my view these groups do not represent politically important elites today ${ }^{2}$. This is a view that I share with I. Werenfels who, in her excellent study on Algerian elites until 2004, excludes these armed groups (specifically, GIA and GSPC) from the main spheres of action of the Algerian elites (Werenfelds 2007). In the author's opinion, even though they had previously championed political objectives, by the beginning of the first decade of the $21^{\text {st }}$ century, their political objectives had become blurred with those of banditry. The same cannot be said of the Islamist parties, starting with FIS, which in the early 1990s came close to the central nucleus of power, and the leaders of which - either divided or exiled - gave their support to Bouteflika in 2004. Neither was this the case with the illegalised Islamist parties (the MSP, en Nahda and el-Islah), which occupied intermediary positions of power from the mid-1990s until the present, bringing the MSP much closer to the central nucleus of power than en-Nahda and, especially, el-Islah. It is these political groups, both legal and illegal, which will be the main focus of the chapter, and I will leave the armed groups for an auxiliary part of the analysis and political account.

2 On the analysis of elites in the Arabic world and on the Algerian context, see (Izquierdo \& Kemou, 2009), and (Bustos \& Mañé, 2009). 


\section{THE GROUPS’ GRASSROOTS AND BACKGROUND OF THEIR ELITES}

The FIS grassroots support crossed class barriers, as it was a populist party that appealed to all sectors of society. Its objective was to correct the mistakes of FLN, its parent party (FIS means "child" in French), and to somehow "save" the Algerian umma from the dangers that lay ahead; hence the name "Islamic Salvation Front". FIS obtained widespread support throughout the country in both the municipal elections of 1990 and the state elections of 1991 (first round). The areas where FIS obtained less support were the less-populated wilayas (provinces) of the country's interior, many of which were the domain of FLN; specifically, these include many of the provinces located on the high plateaus (haut plateaux), especially in the east and the south of the country. Nor did FIS obtain noteworthy results in Kabylia, where the Socialist Forces Front (FFS) turned out to be the main power. The other Islamist parties that took part in the 1991 state elections (though not in those held in 1990, as these parties had not yet been created) obtained minimal support throughout the country, with the exception of Mahfoud Nahnah's Movement for the Islamic Society (MSI, later MSP) in Blida, and Harakat en-Nahda alIslamiyya (at that time led by Sheikh Djaballah) in Constantine and the surrounding region.

Generally speaking, most of the electorate that voted for FIS lived in the urban areas along the country's coastal strip (between the Tell mountain range and the sea), which is the most densely populated zone. Within this geographical and demographic area, the FIS vote was higher among the cities' poorer sectors, often comprised of recently-arrived rural inhabitants who were not entirely accustomed to urban life. This is what some sociologists and Gema $\mathrm{M}$. Muñoz have called the phenomenon of the "rurbanización" (i.e. "rural urbanisation") of cities (Martín Muñoz 1999). It was these de-classed social segments - often young people, not very integrated, in precarious or illegal work situations - which constituted the vast majority of FIS voters.

In contrast, the parties that are legal today - the Movement of Society for Peace (MSP) and the en-Nahda movement (currently made up of en-Nahda and el-Islah) possess a grassroots support that is more localised geographically. As I have mentioned, these parties gained their best results in 1991 in the cities and wilayas where the movement was more deeply rooted, as well as being the areas that the parties' leaders were from. In the case of MSP-Hamas, this was the city and wilaya of Blida (in the centre of the country, some $60 \mathrm{~km}$ south of Algiers), which was the birthplace of the party's leader, Mahfoud Nahnah; as for en-Nahda al-Islamiyya, it was the eastern city of Constantine (the birthplace of its leader, Abdellah Djaballah) and its hinterland. These parties recruited their sympathisers and leaders from wealthier classes than those of the FIS grassroots, many of which were traders and the middle classes of traditional, medium-sized cities.

As for the leaders of the three parties, once again we must make a differentiation between FIS and the legal parties, en-Nahda e Islah and MSP. It is interesting to note (and I do not believe that this has been remarked on previously) that a significant number of FIS leaders (especially the most charismatic ones) came from south-east Algeria, a region better known for its brotherhoods than for its traditions and Islamic studies, Constantine being one of the main cities. This area covers a strip of the high plateaus, the mountains of el-Aurès and the edge of the desert, stretching from the south of Batna through the 
wilayas of el-Oued and Biskra, as well as other provinces on the border with Tunisia. Curiously, this is also the area that other members of the Algerian Ulemas Association were from, including Sheikh Tayeb el-Oqbi (1890-1960), whose name actually derives from the fact that he was a native of Sidi el-Oqba, in the wilaya of Biskra. Meanwhile, Sheikh Soltani, a member of AUMA and a leading Islamist figure who died before the founding of FIS, was born in el-Qantara (Batna) and studied at Sidi Okba zawiya (Cheurfi 1996).

Thus, Abbasi Madani and Ali Benhaj, the number 1 and 2 of FIS, were natives of a town in Biskra and Wadi Souf, a town in the wilaya of el-Oued (near the Tunisian border), respectively. They had completed higher education, as had many other FIS leaders, who included many teachers and engineers who combined their working life with their political and religious activities. Madani taught at the University of Algiers, and had gained a teaching diploma in the United Kingdom. Abdelkader Hachani, the provisional number 1 after the arrest and imprisonment of Madani and Belhaj, was a petrochemical engineer. But the fact is that both Madani and Benhadj, just like other FIS leaders in the Majlis es-shura, came to work and preach in Algiers, following in the footsteps of Sheikh Ahmed Sahnoun. On request of the neighbourhood communities, the latter taught during the 1980s and ' 90 s in popular mosques in the capital, such as the one in the Kouba district and the historic mosque of Ketchoua (Bab el-Oued). It was, in fact, these crowded mosques in the capital city where FIS and its leaders before the party's founding began to gain their many sympathisers and future voters. Recordings of preaching and sermons, and their subsequent dissemination in cassette and video form, helped the leaders to extend their influence to other cities in the country. The Islamic charity associations dedicated to different aims such as building mosques, organising the hajj (the pilgrimage to Mecca), the protection of Islamic heritage and other aid and charity work began to create an organisational network throughout the whole of Algeria which would later after the party was founded - enable them to launch strong electoral campaigns and to mobilise large numbers of voters and sympathisers. Andrea Liverani stresses that this associative framework was the key to the success of the Islamist parties, as well as being a resource that all Algeria's political parties across the political spectrum - from the most secular and left-wing to the most conservative and religious - have used or attempted to use at some time or another to strengthen their political structures (Liverani 2008). It should come as no surprise that this was the same political model that was used by FLN, the single party which for decades was backed by the support of mass organisations (of women, unions, students, farmers, etc.).

\section{THE NATURE OF THE ISLAMIST ACTORS}

As I have made clear, the Islamist actors who are the subject of this study are political parties, all of them backed by associative movements of a religious nature. In the case of FIS, in addition to a network of charity and Islamisation, the party also had a union: the Islamic Workers' Union (SIT). While FIS had an extensive network throughout the country that promoted the party, the Movement of the Islamic Society (HAMAS later renamed the Movement of Society for Peace, or MSP) also had its own associative movement, called "Jamiy'at al-Irshad wa al-Islah" (the Association of Orientation and Reform). Al-Irshad wa al-Islah was founded in the early 1980s by Sheikh Mahfoud 
Nahnah and Sheikh Mohamed Bouslimani. ${ }^{3}$ Meanwhile, the en-Nahda party and, later on, the el-Islah party also had an association, created in 1988, called Jamiy'at an-Nahda li-Islah az-zaqafi wa al-ijtima'i (the Association of Rebirth for Cultural and Social Reform). This became the party base for en-Nahda al-Islami, which later changed its name to en-Nahda after the new political party law of 1997 which forced parties to remove any religious references from their names.

The current situation of Saad Abdellah Djaballah, the leader and founder of the en-Nahda movement, is also worthy of comment from a legal point of view, and because it is illustrative of relations between this political tendency and the regime. In 1999, Djaballah decided to create his own party, after having left en-Nahda because he did not agree with the party leadership's line on collaboration and future incorporation into the government. His new party was called Harakat el-Islah al-Watani, or simply el-Islah, though it is known by the French acronym MRN (Mouvement du Renouveau National). With this party, Djaballah stood for presidential elections in April 1999, ands obtained 400,000 votes (approximately 4\%). Led by Djaballah, El Islah gained good results in the subsequent elections (the state and local elections of 2002 and the presidential elections of 2004; see the Table of Results), until 2007, when the party's leadership launched a surprise attack by holding an extraordinary meeting at which the security officers refused entry to Djaballah and his sympathisers (who numbered approximately 1,000). At this meeting, new directorial posts were appointed (president, general secretary, etc.), and Djaballah was ousted. A court validated the new leadership committee and disqualified Djaballah from the presidency of the party. As a result, Djaballah did not stand in the 2009 presidential elections. In July 2011, Djaballah attempted to return to the political scene by creating his third party, the Front for Justice and Development (FJD), legalised in 2012 with the name of al-Adala (Justice).

In March/April 1992, FIS was dissolved as a party, and thus became illegal. The attempts that have been made to reconstitute it have failed, the most notable being that of Ahmed Taleb Ibrahimi, an Algerian former minister. In 1999, Ibrahimi created the Wafa or Wafa' (Loyalty) party, though it was not given authorisation to operate as a party as most of its founding members had belonged to FIS. The Wafa' spokesman claimed in reply that only 2.5 or $3.5 \%$ (according to sources) had previously been FIS members. In fact, it has not been made clear why an ex-member of FIS should be prevented from exercising his political rights and forming a party, which makes the decision a rather arbitrary matter (Roberts, 2003). Under Algerian law, political rights are revoked for anyone who has been convicted in a court, such as Abbasi Madani and 'Ali Belhadj, the number 1 and 2 of FIS. After having spent 12 years in prison, the two are not allowed to make any public political declarations or, naturally, to form a party or engage in any other political activities. The FIS leadership has become divided as a result of the imprisonments, exile and patent tactical and strategic differences. Apart from the classic split between "Algerianists" and "internationalists", the party's elites were fragmented as their members met one of at least three different fates: some were driven into exile abroad, others were arrested and later freed but denied their political rights, and finally there were others who had returned to Algeria and were (theoretically) allowed to exercise their political rights. The first group included Rabah Kebir (Germany and France), Mourad

3 The latter was co-founder of MSP and president of the association before he was killed by the terrorist anti-Islamist group OJAL (Organisation des Jeunes Algériens Libres) or possibly by GIA (Armed Islamic Group, see above) in November 1993. 
Dhina (France and Switzerland) and Anwar Haddam (EEUU), while in the second group there were A. Madani and A. Belhadj. Meanwhile, Abdelkader Hachani was killed shortly after leaving prison in 1999. The most important name in the third group was Madani Mezrag, the head of AIS, the armed wing of FIS, who took advantage of the first reconciliation initiative following the truce and break-up of AIS (1997 and 2000, respectively). These divisions appear to confirm that reconstituting FIS today would be little short of impossible, not only because of the lack of leaders, but also because the party has lost its grassroots support. Nevertheless, the support several of these figures have given to reconciliation initiatives (at least in terms of their formulation, albeit not in their application) and especially for the candidacy of Abdelaziz Bouteflika in 2004 represent proof that they continue to exert a not-inconsiderable influence on Algerian politics.

In view of the enforced ramifications of FIS abroad, it is important to stress that both the MSP and the en-Nahda movement have claimed affinity to the Muslim Brotherhood (MB) in Egypt. The similarities between the MSP logo and the MB anagram (an open Koran and a religious exhortation) are testament to this. However, it is not clear how far these affiliations or inspirations extend. Algerian law also prohibits all parties from receiving funds from abroad. Neither is it clear what ideological differences separate the MSP from the parties led by Djaballah (en-Nahda al-Islamiyya, el-Islah and now the FJD). Willis notes that, at first, en-Nahda was highly critical of neoliberal privatisation and policy, something that cannot be said of HAMAS-MSP. Willis and other authors have stressed that en-Nahda is doctrinally and tactically closer to FIS than MSP. However, this did not stop Djaballah and other leaders from viewing FIS as radical and opportunist. Perhaps the most important difference between HAMAS-MSP and the Djaballah movement has been their respective relations with the regime, as while the former has always been very close to the government, Djaballah has always upheld a stance of noncollaboration with governments and critical support for the reconciliation process. Admittedly, despite this stance, Djaballah's parties (Nahda and later Islah, until 2007) have never refused to participate in the local administration of the country (local and provincial assemblies).

\section{POWER RESOURCES}

-Ideology. The ideology of FIS can be defined as nationalist, populist and religious. It is this populist element that most clearly distinguishes FIS from its Islamist rivals, en-Nahda al-Islamiyya and HAMAS, and which furthermore enabled FIS to become a political party with mass support (specifically, between 33.6\% and 24.5\% of the electorate, depending on whether we take the 1990 local elections or the first round of the 1991 state elections as our reference). Though the percentage in votes over valid votes stood at around $50 \%$ in both elections, it should be borne in mind that the turnout, which was not particularly high, fell from 65\% in 1990 to 59\% in December 1991, and that FIS lost a total of $1,070,000$ votes in the two elections (Bustos 2004, 411-412). The key moment when FIS revealed its populist nature was at the outbreak of the Gulf War, following the Iraqi invasion of Kuwait in August 1990. While the Algerian authorities attempted to mediate in the conflict and to maintain a balanced stance (which consisted of condemning the invasion at the same time as ruling out any allied intervention), FIS organised mass demonstrations in solidarity with Iraq. According to accounts by military leaders of the 
time, 'Ali Belhadj, one of the leaders of FIS, used to walk around in military attire, and even went so far as to meet up with the commanders-in-chief of the Algerian army dressed like this (Nezzar 1999). This undoubtedly rang alarm bells in military spheres, as it was interpreted as a direct challenge to the Algerian state and its armed forces. This stance broke not only with Algeria's position, but of course (and much more so) with the Arab states that were more conservative and inclined to support Islamism in the Persian Gulf, starting with Saudi Arabia. The possible loss of donations and support from these countries did not cause FIS to back down or moderate its discourse, nor its campaign of mobilisations, and this placed the Algerian government in a serious predicament, as well as sending out a message that did little to calm the Western media. This posture by FIS, which was apparently contradictory with respect to ideology but highly profitable in electoral terms, given that it won over the Arab 'man in the street', has been analysed from opposing stances by H. Roberts $(1991,1994)$ and François Burgat $(1994)$; the former criticises the "misguided opportunism" of FIS, while the latter highlights the populist, pan-Arabist nature of the Algerian party. It goes without saying that this event also distanced FIS from its Islamist rivals, en-Nahda and HAMAS. The elections in December 1991 clearly showed that the populist strategy of FIS had produced a positive result, as the party won 3,262,222 votes compared to the 368,697 gained by HAMAS and the 150,093 votes (approximately) for en-Nahda al-Islamiyya. This translated into 188 seats for the former party, in the first round (in a parliament of 430 ministers), and none for the other two, whatever the results of the second round, which was called off by the Armed Forces.

Another of the strong points of FIS was its anti-system, anti-regime discourse, which fiercely criticised the secular, socialist establishment of independent Algeria, in addition to the modernist elites and sectors with interests in Western countries, especially in France, and which became known as "hizb el-França", or "French party". This antiestablishment discourse, which discredited an entire political, economic and cultural system, resonated profoundly with the poorer sectors, the urban populations that had become declassed, marginalised and non-integrated. The over-simplifying discourse was attractive to many frustrated young people whose expectations had been let down by independent Algeria, in spite of all the revolutionary rhetoric about equality and development. The tone and political stance also set FIS apart from its Islamist rivals, who were much more restrained and moderate in their criticism of the regime and in their solutions to Algeria's problems.

- Funding of the Islamist parties (in the case of FIS, until it was declared illegal and dissolved in 1992) came from public subsidies, the dues paid by their party members and, especially, from donations and economic activities generated by the religious and aid associations associated with the party. There may have been other sources of income, such as donors from abroad, though this was expressly prohibited by Algerian law (art. 56, Party Law 12-04 of 12 January 2012 and art.191 of the Electoral Law 16-10 of 25 August 2016). In particular, the Muslim Brotherhood in Egypt and donors in Saudi Arabia and the Persian Gulf may have funded HAMAS-MSP and the en-Nahda movement, as both parties were very close to the Brotherhood. As I mentioned previously, this channel of funding was blocked for FIS after the Iraq War (1991). 
TABLE OF RESULTS OF ISLAMIST PARTIES AND CANDIDATES IN THE ALGERIAN PLURALISTIC ELECTIONS (1990-2016)

\begin{tabular}{|c|c|c|c|c|c|c|c|c|c|c|c|c|c|c|}
\hline & $\begin{array}{l}\text { Local } \\
1990\end{array}$ & $\begin{array}{l}\text { Parliam } \\
1991 * 1\end{array}$ & $\begin{array}{l}\text { Presid. } \\
1995\end{array}$ & $\begin{array}{l}\text { Parliam } \\
1997\end{array}$ & $\begin{array}{l}\text { Local } \\
1997\end{array}$ & $\begin{array}{l}\text { Presid. } \\
1999 * 6\end{array}$ & $\begin{array}{l}\text { Parliam } \\
2002\end{array}$ & $\begin{array}{l}\text { Local } \\
2002\end{array}$ & $\begin{array}{l}\text { Presid. } \\
2004\end{array}$ & $\begin{array}{l}\text { Parliam } \\
2007\end{array}$ & $\begin{array}{l}\text { Local } \\
2007\end{array}$ & $\begin{array}{l}\text { Presid. } \\
2009\end{array}$ & $\begin{array}{l}\text { Parliam. } \\
2012\end{array}$ & Presid. 2014 \\
\hline FIS & $54.2 \%$ & $47.2 \%$ & ILLEGAL & ILLEGAL & $\begin{array}{l}\text { ILLEGA } \\
\quad \mathrm{L}\end{array}$ & ILLEGAL & ILLEGAL & $\begin{array}{l}\text { ILLEG } \\
\text { AL }\end{array}$ & ILLEGAL & $\begin{array}{l}\text { ILLEGA } \\
\quad \text { L }\end{array}$ & ILLEGAL & $\begin{array}{l}\text { ILLEGA } \\
\quad \mathrm{L}\end{array}$ & ILLEGAL & ILLEGAL \\
\hline $\begin{array}{l}\text { MSP } \\
\text { ex MSI } \\
\text { (Hamas) }\end{array}$ & $\begin{array}{l}\text { DID NOT } \\
\text { EXIST }\end{array}$ & $3.0 \%$ & $\begin{array}{c}25.0 \% \\
\text { (Nahnah) }\end{array}$ & $14.80 \%$ & $9.3 \%$ & $\begin{array}{l}\text { NO PRES. } \\
\text { CAND. }\end{array}$ & $7.7 \%$ & $7.4 \%$ & $\begin{array}{l}\text { NO PRES. } \\
\text { CAND. }\end{array}$ & $9.6 \%$ & $12.6 \%$ & $\begin{array}{l}\text { NO } \\
\text { PRES. } \\
\text { CAND }\end{array}$ & $\begin{array}{c}\text { ALLIANCE } \\
\text { ALGÉRIE } \\
\text { VERTE } \\
6.22 \%\end{array}$ & BOYCOTT \\
\hline $\begin{array}{l}\text { en-Nahda } \\
\text { (Mouvement } \\
\text { en-Nahda, } \\
\text { MN) }\end{array}$ & $\begin{array}{l}\text { DID NOT } \\
\text { EXIST }\end{array}$ & $2.0 \%$ & $\begin{array}{l}\text { NO PRES } \\
\text { CAND }\end{array}$ & $8.70 \%$ & $3.8 \%$ & $\begin{array}{l}\text { NO PRES. } \\
\text { CAND.*3 }\end{array}$ & $0.6 \%$ & $0.4 \%$ & $\begin{array}{l}\text { NO PRES. } \\
\text { CAND. }\end{array}$ & $2.5 \%$ & $2.2 \%$ & $\begin{array}{l}\text { NO } \\
\text { PRES. } \\
\text { CAND }\end{array}$ & $\begin{array}{c}\text { ALLIANCE } \\
\text { ALGÉRIE } \\
\text { VERTE } \\
6.22 \%\end{array}$ & BOYCOTT \\
\hline $\begin{array}{l}\text { el-Islah } \\
\text { (Mouvement } \\
\text { pour la } \\
\text { Réforme } \\
\text { Nationale, } \\
\text { MRN) }\end{array}$ & $\begin{array}{l}\text { DID NOT } \\
\text { EXIST }\end{array}$ & $\begin{array}{l}\text { DID } \\
\text { NOT } \\
\text { EXIST }\end{array}$ & $\begin{array}{l}\text { DID NOT } \\
\text { EXIST }\end{array}$ & $\begin{array}{l}\text { DID NOT } \\
\text { EXIST }\end{array}$ & $\begin{array}{l}\text { DID } \\
\text { NOT } \\
\text { EXIST }\end{array}$ & $\begin{array}{c}4 \% \\
\text { (Djaballah } \\
* 2 \text { ) }\end{array}$ & $10.0 \%$ & $9.3 \%$ & $\begin{array}{c}5 \% \\
\text { (Djaballah) }\end{array}$ & $3.4 \%$ & $2.2 \%$ & $\begin{array}{c}1.4 \% \\
\text { (Younsi) }\end{array}$ & $\begin{array}{c}\text { ALLIANCE } \\
\text { ALGÉRIE } \\
\text { VERTE } \\
6.22 \%\end{array}$ & $\begin{array}{l}\text { SUPPORTED } \\
\text { ALI BENFLIS }\end{array}$ \\
\hline $\begin{array}{l}\text { Ahmed Taleb } \\
\text { Ibrahimi }\end{array}$ & & & & & & $\begin{array}{c}12.53 \% \\
4^{*}\end{array}$ & & & $\begin{array}{l}\text { CAND. } \\
\text { REJECTE } \\
\text { D }\end{array}$ & & & $\begin{array}{l}\text { NO } \\
\text { PRES. } \\
\text { CAND. }\end{array}$ & & $\begin{array}{l}\text { NO PRES. } \\
\text { CAND. }\end{array}$ \\
\hline $\begin{array}{l}\text { Mohamed } \\
\text { Said Belaid *5 }\end{array}$ & & & & & & & & & & & & $0.9 \%$ & & $\begin{array}{l}\text { NO PRES. } \\
\text { CAND. }\end{array}$ \\
\hline Total: & $54.2 \%$ & $52.2 \%$ & $25.0 \%$ & $23.5 \%$ & $13.1 \%$ & $16.5 \%$ & $18.3 \%$ & $17.1 \%$ & $5.0 \%$ & $15.5 \%$ & $17.0 \%$ & $2.3 \%$ & $6.2 \%$ & $0 \%$ \\
\hline
\end{tabular}




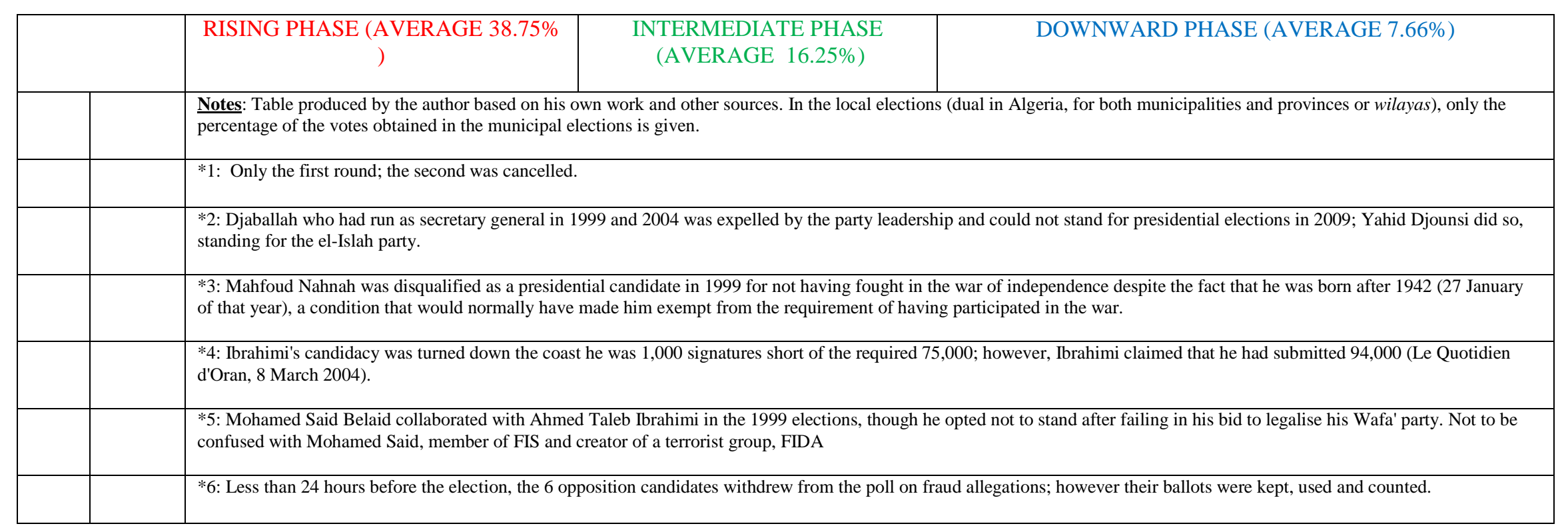


Political parties are not allowed to carry out business activities. Meanwhile, associations cannot (in theory) maintain "organic or structural relations" with political parties, "nor receive funds from them or finance them" (art. 11 of the Associations Law 90-31 of 4/12/1990), and parties cannot maintain relations that are "organic, involving loyalty or dependence with unions or associations", nor "become the section or delegation of a foreign organisation" (arts. 50 and 51 of the 2012 Party Law, respectively). However, in practice, many political parties have maintained close relations with associations and organisations from civil society, including unions, and the Islamist parties are no exception.

Thus, the Algerian Law is highly restrictive with respect to the funding of parties and links with national or foreign organisations, though it is much less strict in practice. The ordinary sources permitted are private donations with a maximum of 300 times the minimum guaranteed salary (for each annual donation), and state subsidies through MPs with seats in the National Assembly. This leaves the door open for informal practices linked with aid and religious activities.

The new Associations Law of 5-12 of 6 January 2012 abrogating the former, despite some concessions, reinforced existing restrictions on all associations and foresaw a specific regime for religious associations. The Law repeated that associations cannot establish links with political parties and should abstain from foreign intervention. Under the projected regulation, religious association must undertake a separate registration process and "respect national unity and the prevailing religious creed of Algerian society". ${ }^{4}$

- Religious and charity associations. If there is one phenomenon that has characterised Algeria's religious panorama since independence arrived in 1962, it is the non-stop building of mosques throughout the country, which has continued to the present day ${ }^{5}$. This growth was exponential, owing in part to public initiative but especially to private funding. The law concerning mosques included a major grey area that enabled Islamists of all tendencies to occupy many places of worship. The law envisaged the naming of an official imam "once the mosque has been completed". But as these were private initiatives, the builders would leave the work unfinished, and their promoters could employ an imam of their own choice (Rouadjia 1990). This became one of the main loopholes for radical imams, though it was also strongly encouraged by the fact that the country was lacking in sufficient numbers of qualified imams for all the new mosques being built. This meant that many imams arrived from the Middle East; men whose ideas and experiences had little or nothing in common with the reality of Algeria, which had experienced an intense, traumatic contact with the West, as well as with socialism and secularism.

As for the contributions and membership fees paid by the members of religious associations, it is hard to gain reliable data on this subject. One of our few sources is Chemine Slimane, the MSP director of communications and one-time member of Jamiat al-Irshad wa al-Islah. In an interview with Andrea Liverani, he claimed that the association had reached a total of 20,000

\footnotetext{
4 Le Quotidien d'Oran, 07/11/2015.

5 In 1962, the number of mosques in Algeria was very low, as many of them were turned into churches or warehouses, but since then they have increased at a dizzying rate $-6,000$ in 1986, 15,000 in 2006, 17,000 in 2013 and possibly 20,000 in 2016, according to data from Algeria's minister of religious affairs (AlgerieFocus 15/11/2013 and Ouest Tribune 6/04/2015). At the same time, associations with religious ends have also increased in number, and represent a considerable proportion of the 11,000 associations created between 1971 and 1987, Ahmed Rouadjia, Les frères et la mosquée. Enquête sur le mouvement islamiste en Algérie (Paris: Karthala, 1990), 78-92. In fact, Andrea Liverani affirmed there were 11,000 religious associations in Algeria (2008: 20). Since 2013 a specific Law on Religious Associations has been debated but not yet adopted; the number of registered associations according to the minister of interior were 15,790 over 96,144 associations of all types (Le Quotidien d'Oran, 11/05/2013).
} 
militant activists and 240,000 members by the early 1990s, but by 2001 (when the interview took place) these figures had fallen significantly, as a result of the violence (two presidents murdered, among other attacks) that forced the party to reduce its activities in many parts of the country. Chemine Slimane acknowledged that even though membership numbers were gradually returning to normal, many members viewed the party with scepticism, as it drained the association of funds and qualified personnel (Liverani 2008).

In tandem with the building of the mosques, a large network of religious and charity associations was also developed. The former were responsible for supervising the building of mosques and organising pilgrimages, while the latter became increasingly important from the 1980s onwards, when the socialist state began to suffer from the effects of the 1986 oil crisis. Austerity policies on public spending began to leave more and more room for civil society to operate, in many cases, in the form of Islamic charity organisations. This explains why, when the first free open elections were held (1990-91), some parties were already backed by an associative network which gave them a huge advantage over the new political parties, especially those of a secular nature, with the exception of those with regional and/or ethnic grassroots support (Kabyles).

In the Islamic world, making private donations to building mosques is a highly prestigious, moral and social act. It is a voluntary action that demonstrates the donor's wealth, but above all his generosity and religiousness. It is often an act that purifies the donor and makes his fortune socially acceptable. It was specifically this channel of funding that brought about the enormous expansion of the associative fabric and mosque-building throughout the country. This channel is one of the most important indirect sources of funding for Islamist parties. The only difference between the three parties is that FIS possessed an extraordinary ability to weave a network of associations throughout the country by making a rather dubious, even aggressive use of the mosques (Leverrier 1995), while the en-Nahda movement always had support that was much more regionally limited to the east of the country. Apart from FIS, only HAMASMSP (which suffered from the same problem of regional isolation - in the central region of Blida) managed to gradually extend its networks throughout the country, as was demonstrated by the more than 1 million votes the party gained in several elections, and the geographical distribution of these votes.

-Potential for mobilising grassroots. The potential that FIS possessed for linear or revolutionary mobilisation derived not only from its nation-wide fabric of associations, but just as much (or more) from its radical populist discourse, which spoke directly to millions of people who felt disinherited and frustrated by the system. In this respect, it was the only one of the three Islamist parties with a potential for linear mobilisation. Both HAMAS-MSP and en-Nahda always adopted circular relations, with clientelistic milieus that were more or less geographically circumscribed, and with the aim of advancing the positions and elitist interests of their leaders. That is the way they have been perceived to date, and it helps to explain why that they reached an electoral maximum that they have been unable to surpass (see Table of Electoral Results). This proximity to power which characterises both parties (MSP and enNahda, as well as el-Islah when Djaballah departed) has caused strong internal tensions, however. Particularly when presidential elections are approaching, the division becomes apparent between those who think they shouldn't present a rival candidate to Bouteflika (and who are hoping to gain power on his ticket), and those who do want to submit their own candidates. The consequences of such friction have tended to be schisms, desertions and often 
a drop in vote and seat numbers in the subsequent elections. In fact, MSP experienced this crisis in 2009, when Abdelmajid Menasra and a group of dissident leaders left MSP to form their own party, the Movement for Preaching and Change (MPC), specifically as a result of this type of disagreements. This all goes to show that these parties exist in an orbit of circular power relations, though the disaffections and schisms also show the attempts made by grassroots members to escape from this dynamic, not to mention the regime's attempts to weaken structures that it considers to be too autonomous.

\section{TYPES OF ACTION AND STRATEGIES WITH RESPECT TO THE REGIME}

\section{Types of action.}

Commencing with FIS, it is clear that the party's actions have been mainly proactive - making decisions and taking the initiative at all times. A clear example of this was when the party declared an indefinite strike and an occupation of public spaces in Algiers in April 1991 with the aim of forcing the government to withdraw the new electoral law with which it was attempting to halt the political progress made by FIS. In contrast, MSP and the en-Nahda movement have typically been reactive in their actions, both to the regime's initiatives and to relations between FIS and the authorities.

With respect to violence, it is true that a large number of tendencies and factions have gravitated around FIS; these groups have been essentially peaceful, though there have been some violent elements. Even before the outbreak of the violence in 1992, a violent episode took place that would be an unfortunate premonition of what came about later. Leaving to one side the terrible events of October 1988 (riots in the main cities, with soldiers shooting into crowds), the final stage of which saw the Islamist militants of FIS taking part, the first outbreak of violence was an attack on the barracks of the gendarmerie in Guemmar (el-Oued), in November 1991. During this attack, the armed group Takfir wa al-Hijra (Excommunication and Exodus) killed several soldiers and appropriated Army weaponry. Admittedly, this group was made up of "Afghans" - ex-combatants from the war in Afghanistan who did not have any links with FIS, beyond that of belonging to the nebulous world of Algerian Islamism. In fact, in the same year, following the arrest of the number 1 and 2 of FIS, the provisional leaders (headed by Abdelqader Hachani) decided to expel Maylis esh-Shura a Said Mekhloufi, the party's head of security, because he had openly declared himself to be in favour of direct action; that is to say, violent action.

To a large extent, FIS was a victim of its own ambition and of the way in which it was manipulated by different sectors of the regime. After 1992, all the leaders who had not been imprisoned or convicted (the Historic Seven at the July trial ${ }^{6}$ ) escaped into exile or went underground. Though they did not opt immediately for the path of armed struggle (unlike other groups, including MEI, MIA, GIA), they finally did so in 1994 following the creation of the AIS, the armed wing of FIS. After the failed attempt of the Sant'Egidio Platform (1995), the AIS entered into negotiations with the Algerian army, which led to the group's dismantling and subsequent break-up (2000). The leaders of FIS (such as their number 5, Abdelqader

\footnotetext{
${ }^{6}$ Abbasi Madani, Ali Belhadj (Benhadj), Kamal Gemazi, Ali Yeddi, Abdelkader Boukhamkham, Omar Abdelkader and Nouredin Chigara were the seven leaders that were all sentenced to jail terms of between four and 12 years at the military court held in July 1992 , a court that has been questioned in terms of its legality. Only the first two served their full terms (12 years) though they were temporarily released to facilitate negotiations; the others were freed in September 1994 Martin Stone, The Agony of Algeria (London: Hurst \& Company, 1997); Hugh Roberts, The Battlefield of Algeria (1988-1992). Studies in a Broken Polity (London: Verso, 2003).
} 
Boukhamkham) and AIS always condemned the violence carried out in their name by other Islamist groups and guerrillas (GIA, GSPC, AQMI), and denied that they represented FIS in any shape or form. In any case, the tendency of FIS was to act in isolation, and to refuse to join existing Islamist parties, whether it was HAMAS or en-Nahda al-Islamiyya. FIS only agreed to become part of the Rabitat ad-daw'a on the understanding that it was a flexible, nonconstricting framework.

The actions of HAMAS-MSP and the en-Nahda movement have always been peaceful; they condemned the radical stance of FIS, instead championing the channels of politics and negotiation. For various reasons and different personal links, En-Nahda has always been closer to FIS than HAMAS has, and has attempted to find a national solution to the illegalisation of the former party. There has been regular contact between the two parties, as well as attempts by en-Nahda at mediation and even at reinstating the leaders of FIS, despite the existing legal limitations. Both of the legal Islamist parties have maintained cooperative relations with the government, especially HAMAS-MSP. This party has had ministers in every Algerian government since the 1997 state elections ${ }^{7}$, including such names as Bouguerra Soltani (minister for SMEs and later for Labour) and Amar Ghoul (minister for Fisheries and Public Works). Furthermore, the party is a member of the Presidential Alliance, which was formed in 1999 and since then has supported the candidacy of Abdelaziz Bouteflika in all the presidential elections. On the basis of this alliance, the MSP has meetings with the other governing parties (FLN and RND), provides ministers for government and refrains from presenting its own candidate for the presidential elections. Djaballah's parties have never held governmental posts, nor have they supported Bouteflika, but they have held seats in parliament, the senate and in local and provincial assemblies. In contrast, following the departure of Djaballah (1999), enNahda has participated in government, in the form of the minister Abdelwahab Derbal. As a reward, Lahbib Adami, the ex-Secretary General of the party, was appointed ambassador for Algeria in Saudi Arabia, while Derbal, when his mandate ended, was appointed ambassador for Algeria to the Arab League (Sfeir 2009).

\section{Strategies}

In light of the above, it is obvious that of the three parties, HAMAS-MSP had the clearest, most stable strategy, which could be described simply as loyalty to the regime. It has unquestionably been the Islamist party with the closest relation with the authorities, and it probably was so even before the founding of the party, when Chadli Bendjedid, the president at that time, decided to give a reprieve to Mahfoud Nahnah, who was serving his sentence in prison. As I have described previously, the strategy of FIS has fluctuated between covert confrontation (until March 1992 or even 1994, when AIS was created) and open or declared confrontation. Admittedly, however, FIS has often shown signs of moderation, such as when it presented itself for election in 1991, in spite of the fact that all its leaders were imprisoned, or when it joined other parties in signing the Sant'Egidio Platform for Peace in 1995. FIS was quite clearly unable to control or stop the spiral of violence and the emergence of armed groups that used increasingly radical methods, which began with breaking the taboo of attacking civilians (GIA, MEI, FIDA), then attacking foreigners (GSPC) and finally using suicide bombers to spread panic and cause great destruction (AQMI).

7 Previously he was Secretary of State for Fisheries in the government of Ahmed Ouyahia, formed in December 1995. 
The strategy of the en-Nahda movement has also been essentially ambivalent, opting (depending on its leaders at the time) for critical support of reconciliation policies, including support for their promoter, President Bouteflika, or for more thorough criticism of the way these policies were applied, the continuation of authoritarianism and the government's neoliberal policies (in line with Djaballah's opinions). In practical terms, this strategy has fluctuated between non-confrontation (passivity and entryism into the government) and covert confrontation, marked by the party's refusal to allow itself to be co-opted. While the passive strategy of non-confrontation resulted in access to ministries and embassies (en-Nahda from 1999 onwards), the strategy of strong opposition and not allowing one's party to be co-opted (a feature of Djaballah's parties) resulted in these parties being infiltrated, "divided" by administrative or judicial intervention and gradually weakened in Parliament (see Table of Results).

\section{CIRCULAR OR LINEAR POWER RELATIONS}

As we have already seen from its relations with the regime, FIS has been the only one of the three Islamist parties and movements with a potential for mobilising its grassroots support. Though, on the occasion of the reform of the Family Code (Personal Statute) in 2005, there was a considerable amount of Islamist mobilisation to call for the Statute to maintain its conservative nature based on a restrictive interpretation of the shariy'a, this can only be considered an exception to the dominant trend. This was an exception because, furthermore, it touched on the central nucleus of the Islamist parties' ideological programmes - the family. Leaving this event to one side (and which, in any case, was not aimed at advancing the interests of a specific group, but at preventing the emancipation of women in a secular, progressive sense $^{8}$ ), neither MSP nor the en-Nahda-el-Islah movement can be said to have mobilised their grassroots supporters to achieve social or political objectives that would have benefited the social strata they claim to represent.

As for FIS, the potential for mobilisation and, therefore, for linear power relations that the party enjoyed for several years was not made suitable use of, and the maximalism of the party's leaders brought about the collapse of the party, its leaders and the associations that supported them, all of which were vigorously dismantled and repressed. The mobilisations organised by FIS in the years 1988-91 were mostly for the purpose of defending the popular objectives that the party claimed to embody. Nevertheless, the hazardous trial of strength that FIS embarked upon led to the party being manipulated by the regime and losing control of the situation, a circumstance that objectively separated the party from its sympathisers. The outbreak of violence cannot logically be considered to be something that was desired by the grassroots supporters of FIS, nor by Algerian society, apart from the suffering and enormous cost that it represented for society as a whole. The participation of FIS in the events of October, with the resulting death toll, represented a demonstration against the system and a demand for urgent change in the country. Some leaders of FIS, such as Ali Belhaj, who had participated in the demonstrations, met with the authorities in the days that followed to discuss responsibility for the deaths and changes in the country. Many of these changes were introduced the following year, with the new constitution, the abandonment of socialism, multi-party elections, etc. This did not mean, however, that the so-called Algerian "reformers" were applying the programme

${ }^{8}$ It should be noted that most of the progressive and feminist media called for the government to go beyond this timid reform and to completely repeal the reactionary Family Code of 1984 . 
or the wishes of the Islamist movement; they applied their own programme, though clearly it coincided in part with the interests and objectives of the Islamist movement.

The campaign against the Iraq war and in solidarity with Iraq organised by FIS in early 1991 reflected popular feeling but did not truly seek either to impose this viewpoint on the government (which was politically unrealistic and highly risky) or to call its electors' attention to the radical nature of its proposals and to set a distance between itself and FLN and the government. In this respect, the request FIS made to the Algerian government that it should send FIS volunteers to defend the Iraqi people can be interpreted more as a populist, electoral manoeuvre than as a true expression of the interests of the Algerian people.

Finally, the episode of the indefinite strike and the occupation of squares in protest against the Electoral Law of April 1991 was an attempt to ensure that FIS was not denied victory (as had been the case a year earlier) in the local elections. Though the objective can be considered legitimate and a reflection of popular feeling, the pressure exerted on what was a weak government in the middle of a process of transition and change only created more tension and forced the Army to intervene in the administration of the political process. The maximalism of the leaders of FIS - which at that time was governing over half of the country's town councils - did not chime well with the interests of the social classes that the party represented. In any event, it was a risky gamble that led to the arrest of the party's two main leaders and the creation of a climate of pre-violence that was marked by the attack on Guemmar gendarmerie. This radicalisation, tempered by the stance taken by the new provisional government to participate in the elections, ended up by alienating many citizens at the polls. Turnout dropped by $6 \%$ compared with the previous year, and FIS lost 1,074,000 votes throughout the country (Bustos 2004). Worse still, it all served to create a climate of alarm and fear which precipitated the mobilising of not only the Army, but also pressure from the country's secular sectors, women's associations, the sole ex-union and the international media to call off the second round of the elections.

These three episodes clearly show that the leaders of FIS chose to make use of the party's influence and its capacity for popular mobilisation in order to negotiate face-to-face with the regime. Driven on by this desire, FIS as a party sought maximalist gains that would directly benefit the political organisation, but not the interests of its grassroots supporters. Empowered by the apparent success of the events of October 1988 and the resulting political openness, the party felt confident enough to pressure the regime into granting it concessions by bringing the masses out onto the streets. But it was specifically here that the party made its mistake, as the tactic brought a rapid reaction from the Army and from many secular, progressive circles, as well as creating a dangerous tension that alienated voters in general and the party's sympathisers in particular. On these and other occasions, FIS chose to act alone, setting itself apart from other political parties (except for the case of the negotiations for the Sant'Egidio Platform of 1995), either out of a fear of infiltration by the state or from a belief that the party's true strength lay in acting alone. In all these cases, FIS could have upheld the interests of its grassroots supporters better by seeking synergies and support from other parties, but unfortunately it did not do so, and the party only realised its mistake and tried to rectify it in 1995, by which time the conflict was unstoppable because other, more radical groups had come onto the scene who did not adhere to the same political way of thinking. 


\section{CONCLUSIONS}

In this piece I have carried out a fundamental study of the most recent Islamist political parties (FIS, en-Nahda and MSP-HAMAS), touching only briefly on the armed Islamist groups, as they are not considered politically important elites. I have attempted to show that these parties, just like the rest of Algerian society, have used and continue to find support in associative networks. In the case of Islamist parties, these networks are much denser and more extensive than those of other, secular parties. This has been caused by sociological reasons, combined with the exponential growth of mosques and the social prestige gained by making donations for religious ends. Both MSP-HAMAS and en-Nahda al Islamiyya were created on the foundations of Islamic religious and charity associations (Jamiy'at el-Irshad wa al-Islah and al Jamiy'at en-Nahda li-Islah az-zaqafi wa al-iytima'i). While it was a legal party, FIS was supported by a network that was less centralised but much more widely spread, and which broke through all regional limits or those based on clientelistic fiefdoms. The fundamental features in these networks were the mosques and the party's populist, radical discourse, which was easily accessible and direct in its criticism of the regime, unlike that of its Islamist rivals, MSP and en-Nahda al-Islamiyya.

Following the illegalising and dismantling of FIS, HAMAS-MSP and en-Nahda alIslamiyya embarked on different political strategies to try and take advantage of the enormous power vacuum left by FIS. While the MSP's strategy clearly adhered to a policy of loyalty, cooperating closely with the regime and forming part of the governmental coalitions and the "presidential alliance" that supported the president Abdelaziz Bouteflika, en-Nahda fragmented into at least three parties (en-Nahda, el-Islah and Abdellah Djaballah's FJD), specifically as a result of its vacillating between following a strategy of non-confrontation with the regime, leading to its co-opting and a strategy of covert confrontation, opposed to making concessions or entering into the dynamic of the system. These strategies, which are framed within secular power relations, explain why none of these legal parties has, to date, succeeded in filling the hole left by FIS; in fact, not only have they failed to reach electoral representation figures similar to those of FIS, furthermore (as the Table of Results shows) they have experienced a marked downward trend. This has led some authors to speak of "the failure of the political participation of Islamism"9 (Boubekeur 2010). However, it is significant that almost 20 years after the FIS was declared illegal, another amnesty was declared in 2012 for more than 7,000 Islamist prisoners (mostly from FIS-AIS) who were jailed for non-violent crimes. ${ }^{10}$ Nevertheless, the eventual return of FIS politicians or the lift of the ban on the party should not be overemphasized, since it is a recurrent theme that has never been materialized.

\footnotetext{
9 In fact, in the 2012 legislative elections, despite the fact that three major Islamist parties stood together in an Alliance (the MSP, en-Nahda and Islah), they were not able to surpass $(6,2 \%)$ the sum of their individual scores in former polls, over $15 \%$ (see Table of Results), provoking an immediate accusation of fraud. ${ }^{10}$ See, for example, the office of Europa Press, “Bouteflika considers freeing Algerian Islamists imprisoned since the 1990s”, 16 May 2011, or the report by Isabelle Mandraud that appeared in Le Monde on 24 May 2011 under the title “Algérie: Le FIS négocie son retour en politique” Isabel Mandraud, "Are Algeria’s Islamists Ready To Make A Political Comeback?," Le Monde 2011.
} 


\section{BIBLIOGRAPHY}

Boubekeur, Amel. 2010. L'islamisme algérien: de la reconciliation à l'échec de la participation politique. Paris: EHESS and Algérie Débat.

Burgat, François. 1994. "Après la crise du Golfe: jalons pour l'analyse de la mobilisation islamiste au Maghreb." In El Magreb tras la crisis del Golfo: transformaciones políticas y orden internacional, edited by Juan Montabes Pereira and Bernabé López García, 263-272. Granada: AECI y Universidad de Granada.

Bustos, Rafael. 2004. El cambio político en Argelia (1988-1992). Análisis sistémico de una transición discordante. PhD Dissertation. Madrid: Universidad Complutense de Madrid.

2010. "Elecciones y cambio político en Argelia (1962-2009)." In Entre el autoritarismo y la democracia. Los procesos electorales en el Magreb, edited by María Angustias Parejo. Barcelona: Ediciones Bellaterra.

Bustos, Rafael and Aurèlia Mañé Estrada. 2012. “Algeria: Post-Colonial Power Structure and reproduction of Elites Without Renewal” (S. E. y. A. D. B. C. Arnette, Trans.). In Political Regimes in the Arab World. Society and the Exercise of Power edited by Ferrán Izquierdo, 38-64. Abingdon: Routledge (Taylor and Francis Group).

Cheurfi, Achour. "el-Okbi, Tayeb " En Memoire algérienne. Dictionnaire biographique, editado por Achour Cheurfi. Algiers: Dahleb Edition, 1996.

—_. "Soltani, Abdelatif." En Memoire algérienne. Dictionnaire biographique, edited by Achour Cheurfi. Algiers: Dahleb Edition, 1996.

Izquierdo, Ferrán and Athina Kemou. 2009. "La Sociología del poder en el mundo árabe contemporáneo." In Poder y regímenes en el mundo árabe contemporáneo, edited by Ferrán Izquierdo, 17-60. Barcelona: Bellaterra y CIDOB.

Leverrier, Ignace. 1995. "El Frente Islámico de Salvación entre la prisa y la paciencia." In Las políticas de Dios, edited by Gilles Kepel, 27-71. Madrid: Anaya \& Mario Muchnik.

Liverani, Andrea. 2008. Civil society in Algeria : the political functions of associational life. Londres: Routledge.

Mandraud, Isabelle. 2011. "Are Algeria’s Islamists Ready To Make A Political Comeback?" Le Monde. 24 may.

Martín Muñoz, Gema. 1999. El estado árabe. Crisis de legitimidad y contestación islamista. Biblioteca del Islam contemporáneo. Barcelona: Edicions Bellaterra.

Martinez, Luis. 2010. "Algeria." In Guide to Islamist Movements, edited by Barry Rubin, 21128. Armonk (NY); London: M. E. Sharpe.

Nezzar, Khaled. 1999. Mémoires du général Khaled Nezzar. Batna, Algeria: Chihab Éditions.

Roberts, Hugh. 2003 The Battlefield of Algeria (1988-1992). Studies in a Broken Polity. London: Verso.

1994. "From Radical Mission to Equivocal Ambition: the Expansion and Manipulation of Algerian Islamism." In The Fundamentalist Project: American Academy of Arts and Sciences, edited by Martin E. Marty and R. Scott Appleby, 428-89. Chicago: University of Chicago Press.

1991. "A trial of strength: Algerian Islamism." En Islamic fundamentalists and the Gulf Crisis, edited by James Piscatori, 131-54. Chicago: University of Chicago Press.

Rouadjia, Ahmed. 1990. Les frères et la mosquée. Enquête sur le mouvement islamiste en Algérie. Paris: Karthala.

Sfeir, Antoine, ed. 2009. Dictionnaire géopolitique de l'islamisme. Montrouge, France: Bayard Éditions. 
Stone, Martin. 1997. The Agony of Algeria. London: Hurst \& Company.

Werenfels, Isabelle. 2007. Managing Instability in Algeria. Elites and Political Change since 1995. London/New York: Routledge. 